\title{
The Conscientious Objector and the First Amendment: There but for the Grace of God .....
}

The concept of legislative grace has long been accepted as the basis of the conscientious objector exemption. ${ }^{1}$ In Hamilton $v$. Regents ${ }^{2}$ and United States $v$. Macintosh ${ }^{3}$ the Supreme Court, relying on the

1 Although Congress had always made some special provision for conscientious objectors when authorizing conscription, the Selective Training and Service Act of 1940, ch. 720, $\$ 5$ (g), 54 Stat. 899 (1940), provided the broadest exemption known up to that time:

Nothing contained in this Act shall be construed to require any person to be subject to combatant training and service ... who, by reason of religious training and belief, is conscientiously opposed to participation in war in any form.

Because there was some question as to whether belief in a deity was required under the terms of the exemption, compare United States v. Kauten, 133 F.2d 703 (2d Cir. 1943), with Berman v. United States, 156 F.2d 377 (9th Cir.), cert. denied, 329 U.S. 795 (1946), Congress, when substantially reenacting the former law in the Military Training and Service Act of 1948, \& 6 (j), 62 Stat. 613 (1948), 50 U.S.C. App. § 456 (j) (1964), added:

Religious training and belief in this connection means an individual's belief in a relation to a Supreme Being involving duties superior to those arising from any human relation, but does not include essentially political, sociological or philosophical views or a merely personal moral code.

For an extensive treatment of the history of the exemption see generally U.S. SEIECTIVE SERvice SYSTEM, Conscrentious OBJECTION 29-65 (Special Monograph No. 11, 1950); Conklin, The Conscientious Objector Exemption: $A$ View in the Light of Torcaso $\%$. Watkins, 51 Gro. L.J. 252, 256-63, 269-76 (1963); Russell, Development of Conscientious Objector Recognition in the United States, 20 GEO. WASF. L. REv. 409 (1952). The "exemption" is strictly from combatant military service, not from service entirely, and for this reason the Selective Service System considers the exemption to be only the allowance of an "alternative form of service." There are two kinds of service available to the objector; noncombatant service in the armed forces for those who are opposed only to the bearing of arms, 32 C.F.R. § 1622.11 (1962), and civilian work of national importance, primarily hospital and social welfare work, for those who are opposed to any participation in military service, 32 C.F.R. § 1622.14 (1962).

2293 U.S. 245, 266-68 (1934) (Cardozo, J., concurring) (classes in military science requiring the bearing of arms even though contrary to religious belief may be made compulsory at a state university).

3283 U.S. 605, 624 (1931) (conscientious objector may not become a naturalized citizen because the required oath exacts a promise to bear arms). This case was overruled by Girouard v. United States, 328 U.S. 61 (1946), on the grounds that the earlier case made an erroneous statutory construction. The extraordinary procedure of disturbing a settled statutory construction, see LEvI, AN INTRODUCIION TO LEGAL REASONING 32-33 (1948), hints of constitutional considerations, and weakens the force of the constitutional dicta in Macintosh, dicta heavily relied on in Hamilton. 
Selective Draft Law Cases, ${ }^{4}$ stated that the exemption may be revoked at will, or not granted at all, because it is only a privilege extended by Congress in the exercise of its plenary war powers. Congress, ${ }^{5}$ lower federal courts, ${ }^{6}$ and the Selective Service System ${ }^{7}$ have echoed this doctrine. With some variation, it has also been followed by almost all of the commentators. ${ }^{8}$ However, the validity of the "privilege" argument, based on cases decided more than three decades ago, is questionable in light of the Court's more recent decisions $^{9}$ construing the religion clauses. ${ }^{10}$ Therefore it is timely to reexamine the constitutional status of the conscientious objector exemption. To this end two questions will be considered by this comment. First, is an exemption for conscientious objectors required by the religion clauses of the first amendment ${ }^{11}$ Second, if the exemption is constitutionally compelled, what is its necessary scope?

4245 U.S. 366, 389-90 (1918) (World War I draft law does not violate either establishment or free exercise clause.)

5 S. REP. No. 1268, 80th Cong., 2d Sess. 14 (1948).

6 E.g., United States v. Bendik, 220 F.2d 249 (2d Cir. 1955); United States v. Kime, 188 F.2d 677, 678 (7th Cir.), cert. denied, 388 U.S. 947 (1950); Richter v. United States, 181 F.2d 591, 593 (9th Cir.), cert. denied, 340 U.S. 892 (1950); United States v. Kenstler, 250 F. Supp. 833, 834 (W.D. Penn. 1966).

7 U.S. Selective Service System, Legal Aspects of Selective Service 8 (1963); 2 U.S. Selective Service System, The Selective Service Act 407 (Special Monograph No. 2, 1954).

8 See, e.g., Drinan, Religion, the Courts and Public Policy 15-20 (1963); Katz,

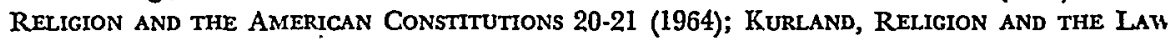
37-38 (1962) (exemption of questionable constitutionality); Pfeffer, Church, State anc FREEDOM 505 (1953); Clancy \& Weiss, Conscientious Objector Exemption: Problems in Conceptual Clarity and Constitutional Considerations, 17 Me. L. REv. 143, 159 n.85 (1965); Conklin, supra note 1, at 280 (exemption unconstitutional); Rabin, When Is a Religious Belief Religious: United States $v$. Seeger and the Scope of Free Exercise, 51 CoRNell L.Q. 231, 241 n.59 (1966); Comment, The Conscientious Objector Exemption: Still Unsettled, 33 GEO. WASH. L. REv. 1108, 1118-23 (1965); Comment, The Three Eras of the Conscientious Objector, 34 U. CrNc. L. REv. 487, 496 (1965). But see Brodie \& Southerland, Conscience, the Constitution and the Conscientious Objector; The Riddle of United States v. Seeger, 1966 Wrs. L. REv. 306, 319-27; Freeman, Exemptions From Civil Responsibilities, 20 OHIO Sr. L.J. 437 (1959).

9 See, e.g., Sherbert v. Verner, 374 U.S. 398 (1963); School District v. Schempp, 374 U.S. 203 (1963); Torcaso v. Watkins, 367 U.S. 488 (1961); Everson v. Board of Education, 330 U.S. 1 (1947), Murdock v. Pennsylvania, 319 U.S. 105 (1943).

For an excellent discussion of the "privilege" cases and an estimate of their current strength as precedent, see generally Mansfield, Conscientious Objection-1964 Term, 1965 ReLigion AND THE PUBLIC ORDER 1, 60-66.

10 "Congress shall make no law respecting an establishment of religion or prohibiting the free exercise thereof . . . U.S. Const. amend. I.

11 For the purposes of this discussion it will be assumed that the scope of the exemption is settled law and includes all people who might properly be called religious objectors. 
Conscientious Objection and the First Amendment: THEORIES AND RESULTS

Four major theories of the religion clauses have been defended by the commentators. Three closely related theories-neutrality, accommodation, and separation-have received explicit support in expressions from the Court. These three differ primarily in the relative weights they give to the two religion clauses. The neutrality theory appears to give equal weight to the two clauses; ${ }^{12}$ the accommodation theory emphasizes the free exercise limitation on governmental interference with religious activity; ${ }^{13}$ and the separation theory emphasizes the establishment clause limitation on governmental activity with respect to religion. ${ }^{14}$ The fourth theory, whose chief proponent is Professor Kurland, differs substantially from the other three. Kurland suggests that the religion clauses must be read together, rather than balanced, and that so read they prohibit all governmental action based on any classification in terms of religion. ${ }^{15}$

\section{A. The Neutrality Theory}

Although the neutrality theory of the religion clauses has frequently been espoused, if not followed, by the Court, it was not until the most recent cases under the religion clauses, School District v. Schemp $p^{16}$ and Sherbert $v$. Verner, ${ }^{17}$ that the Court attempted to formulate a clear standard for its application. ${ }^{18}$

In Schempp, while holding that Bible reading in the public schools was an unconstitutional establishment of religion, Mr. Justice Clark announced the Court's support of the principle of neutrality. He began with the establishment clause:

[The Establishment Clause] withdrew all legislative power

12 See generally Howe, The Garden aNd the Wilderness (1965); Katz, ReLiGion and THE AMERICAN Constitutions (1964).

13 See generally Kauper, Religion and the Constitution (1964).

14 See generally Pfefrer, Church, State and Freedom (1953).

15 See generally KURLAND, RELIGION AND THE LAW (1962).

16374 U.S. 203 (1963).

17374 U.S. 398 (1963). While the Court didn't frame the issues in this case in terms of the neutrality theory as it had done in Schempp, it is clear from the opinion that the Court felt that it was operating under that theory. Id. at 409. Even the dissenters seem to grant this point, for their complaint is that the majority follows the neutrality theory too closely. Id. at 422 .

18 In prior cases the Court apparently had great difficulty in devising standards for the neutrality theory. See School District v. Schempp, 374 U.S. 203 (1963); Kurland, The School Prayer Gases, in The Wall Between Church and State 148, 159-60 (Oaks ed. 1963). 
respecting religious belief or the expression thereof. The test may be stated as follows: what are the purpose and the primary effect of the enactment? If either is the advancement or inhibition of religion then the enactment exceeds the scope of legislative power as circumscribed by the Constitution. ${ }^{10}$

This test was derived from $M c$ Gowan $v$. Maryland, ${ }^{20}$ where the validity of a Sunday closing law was upheld because, although its purpose and effect initially involved religion, the law's rationale had long since changed; at the time the case was decided it was clear that the law simply provided "a uniform day of rest for all citizens." 21 In Schempp, however, the Court found that the purpose and effect of the state's action in instituting Bible reading were to conduct a religious ceremony, ${ }^{22}$ an action clearly advancing purely religious interests. Most of the other establishment clause cases, while apparently based on different rationales, are consistent with $M c$ Gowan and Schempp. For example, in Everson v. Board of Education, ${ }^{23}$ which sustained reimbursement of transportation expense to parents of children at public, private non-sectarian, and parochial schools, the primary purpose and effect of the legislation was the promotion of the safety of the students at these schools. ${ }^{24}$

19 School District v. Schempp, 374 U.S. 203, 222 (1963).

20366 U.S. 420, 442-44, 445 (1961); see Braunfeld v. Brown, 366 U.S. 599, 607 (1961).

21 McGowan v. Maryland, 366 U.S. 420, 445 (1961).

22 School District v. Schempp, 374 U.S. 203, 224 (1963).

23330 U.S. 1 (1947). This is the first case in which the Court spoke in terms of neutrality. Id. at 18.

24 The actual rationale for the decision was that the legislation was designed to benefit the children attending these schools and not the religious schools themselves. $I d$. at 7,14 , 17, 18. This child benefit theory first appeared in Cochran v. Louisiana, 281 U.S. 370 (1930), which dealt with the provision of textbooks on the same basis as the transportation in Everson. Cochran was, however, decided under the due process clause, not under the religion clauses.

Other examples of the Schempp purpose and effect rationale may be seen in Engel v. Vitale, 370 U.S. 421 (1962) (use of the New York Regent's Prayer violates the establishment clause: purpose and effect of holding a religious ceremony); Torcaso v. Watkins, 367 U.S. 488 (1961) (Maryland constitutional provision requiring public officers to swear to their belief in God invalid: effect, if not purpose, of excluding nontheists from public office); Illinois ex rel. McCollum v. Board of Education, 333 U.S. 203 (1948) (released time religious instruction violates the establishment clause; purpose and effect of encouraging religious instruction). But see Zorach v. Glauson, 343 U.S. 306 (1952) (released time religious instruction off school property constitutional).

Everson and Torcaso are reasoned from a principle which forbids preference among religions or between religion and non-religion. 330 U.S. at 15-16; 367 U.S. at 495 . McCollum, while following Everson, seems to rest on the state's use of the compulsory school attendance mechanism to aid religious groups in spreading their faith. 333 U.S. at 208-11. 
With respect to the free exercise clause, however, Mr. Justice Clark's statements in Schempp did not encompass the precedents quite as neatly:

The Free Exercise Clause . . . withdraws from legislative power ... the exertion of any restraint on the free exercise of religion. Its purpose is to secure religious liberty in the individual by prohibiting any invasions thereof by the civil authority. Hence it is necessary in a free exercise case for one to show the coercive effect of the enactment as it operates against him in the practice of his religion. ${ }^{25}$

Unfortunately this scheme of analysis based on an absolute prohibition of all "coercive" restraints on free exercise did not last even as long as the very next religion clause case, decided the same day as Schempp. In Scherbert v. Verner ${ }^{26}$ South Carolina had denied unemployment compensation to a claimant who, because she was a sabbatarian, would not accept jobs necessitating Saturday work as required by state law in order to qualify for compensation. The Court held that the denial of compensation infringed the claimant's rights under the free exercise clause. Although the state's rule forced the claimant to choose between the unemployment compensation and one of the tenets of her faith, a clear coercive restraint on her free exercise as delineated in $S c h e m p p, 27$ the decision was not supported by reference to the Schempp principle. ${ }^{28}$ Instead, the Court returned to the long line of free exercise

Engel, which cites no cases, seems to follow McCollum in finding the prayer part of a program to further religious beliefs. 370 U.S. at 429-31.

25 School District v. Schempp, 374 U.S. 203, 222-23 (1963).

26374 U.S. 398 (1963).

27 The difference in tone between the two opinions is partly accounted for by the fact that the author of the Sherbert opinion was Mr. Justice Brennan, whose concurrence in School District v. Schempp, 374 U.S. 203, 230-304 (1963), indicated that his idea of neutrality was somewhat more latitudinarian than that of Mr. Justice Clark. See Kurland, The School Prayer Cases, in The Wall Between Church AND State 143, 163-68 (Oaks ed. 1963).

28 At least one reason why the principle was ignored was that some interference with religious practice had been allowed by the Court in past cases. Braunfeld v. Brown, 366 U.S. 599 (1960) (Sunday closing law may be applied to an Orthodox Jewish merchant); Prince v. Massachusetts, 321 U.S. 158 (1944) (distribution of religious tracts may be regulated under child labor laws); Hamilton v. Regents of the Univ. of Calif., 293 U.S. 245 (1934) (classes in military science requiring the bearing of arms even when contrary to religious beliefs may be made compulsory at a state university); Reynolds v. United States, 98 U.S. 145 (1878) (bigamy statute may be applied to Mormon who finds it his religious duty to practice polygamy). 
precedents in what may have been an attempt to formulate a more workable statement of the free exercise portion of the neutrality theory.

Drawing from these cases, the Court began with the distinction, first enunciated in Reynolds $v$. United States, ${ }^{29}$ between religious belief and religiously motivated action, and then it continued by distinguishing direct and indirect burdens on free exercise, as was done in Braunfeld $v$. Brown. ${ }^{30}$ Neither of these distinctions had been of much help in solving problems under the free exercise clause in the past, and their record was not improved by this application. ${ }^{31}$ The reasons for their failure are numerous. While the distinction between "action" and "belief" helps to explain some of the cases, ${ }^{32}$ it does not indicate what differentiates "action" from "belief," 33 nor does it define

2998 U.S. 145 (1878). The defendant claimed that prosecution for bigamy was a denial of free exercise to one who held the practice of polygamy a religious duty. While stating that the imposition of any restraints on religious belief would be unconstitutional, the Court denied the Mormon's claim and upheld this restraint on religiously motivated action because the practice was "in violation of social duties or subversive of good order." Id. at 164. See also Sherbert v. Verner, 374 U.S. 398, 403 (1963) ("The conduct or actions so regulated have invariably posed some substantial threat to public safety, peace or order."); Cantwell v. Connecticut, 310 U.S. 296, 303-04 (1940) (“[T]he Amendment embraces two concepts, - freedom to believe and freedom to act. The first is absolute but ... the second cannot be. Conduct remains subject to regulation for the protection of society.").

30366 U.S. 599 (1961) (Pennsylvania's Sunday closing law does not deny the free exercise of religion to an Orthodox Jewish merchant, who by reason of his religious beliefs could not open his shop on Saturday, and would lose his livelihood if unable to operate on Sunday). The Court stated that laws which outlaw religious practice impose a direct burden on the individual and are usually invalid. All other laws which infringe on free exercise are indirect burdens and may be sustained if they are shown to have a secular purpose, "unless the State may accomplish its purpose by means which do not impose such a burden." Id. at 607 .

31 Were the Court to explain the interrelationship between the action-belief dichotomy and the direct-indirect burden concept, perhaps some clarification of doctrine would result. It may be suggested that the direct-indirect burden concept is an attempt at recategorization of those "actions" with which the government may interfere. It is not clear, however, whether the resulting class of permissible limitations is identical to that classification under the previous action-belief test, simply determined in a different manner; or whether it is different. If different, it is still more unclear how and why it is different.

32 See, e.g., Torcaso v. Watkins, 367 U.S. 488 (1961) (a state may not compel the affrmation of a repugnant belief); Murdock v. Pennsylvania, 319 U.S. 105 (1943) (the state may not tax religious colporteurs so as to inhibit the dissemination of religious views); Cantwell v. Connecticut, 310 U.S. 296 (1940) (a state may not regulate solicitation in a way which, through the method of determining what is a religious cause, tends toward censorship of belief). Each may be viewed as an attempt at regulating belief. Permissible regulations of action are Reynolds and Prince v. Massachusetts, 321 U.S. 158 (1943) (free exercise no defense to a prosecution under child labor laws).

33 If the distribution of religious tracts is "belief" which may not be regulated in 
with precision the limits to action pursuant to religious belief. ${ }^{34}$ Furthermore, it does not explain the divergent results in Braunfeld and Sherbert, decided only two years apart and analytically almost identical. ${ }^{35}$ Nor can the direct and indirect burden distinction ${ }^{36}$ adequately distinguish these two cases. ${ }^{37}$

Murdock and Cantwell, why is it not still "belief" in Prince? The distinction is not based on the Reynolds rationale; rather it is in the greater scope of state authority over children than adults. Prince v. Massachusetts, 321 U.S. 158, 167, 170 (1944).

34 The threat to the social order is not the same from bigamy in Reynolds, child labor in Prince, and unlicensed solicitation in Murdock; why is child labor more like bigamy (action) than unlicensed solicitation (belief)? The results seem consistent, yet are by no means indicated by the distinction between action and belief. A simple balancing of state and individual interests would seem to be the best explanation of the standard applied in these situations. Thus, the state has greater interest in maintaining social patterns which it feels are conducive to a stable society by forbidding practices like bigamy and child labor than it has in regulating the dissemination of religious views. The individual has a greater interest in getting his views disseminated (Murdock) than in the manner in which those views are disseminated (Prince). In these two cases strong and weak interests are paired. Assuming the extremely debilitating effect of permitting two forms of marriage to exist in one society, as the Court in Reynolds did, the state interest in maintaining a stable society is greater than the strong individual interest in pursuing the form of marriage he wishes.

35 The choice presented to the plaintiff in both cases was economic loss or abandonment of religious practice. In both cases the Court found that religious belief, as opposed to action, was not impaired by the state's regulation and in neither was it willing to justify the state's statute on the grounds that it was a permissible regulation of religious action. They may perhaps be tenuously distinguished on the ground that the economic loss in Braunfeld was brought about through competition, while that in Sherbert was brought about through the withholding of a governmental subsidy, a competetive loss in only a very attenuated sense.

36 Exactly what is a "religious practice," seemingly crucial to the direct-indirect burden analysis, is nowhere stated. The term seems limitless, and has even been held to include snake handling, Lawson v. Commonwealth, 291 Ky. 437, 164 S.W.2d 972 (1942), and the consumption of peyote, People v. Woody, 61 Cal. 2d 716, 394 P.2d 813, 40 Cal. Rptr. 69 (1964). Moreover, why the distinction turns on "religious practice" is not self-evident. "Religious practice" seems to be a rather arbitrary division obscuring a continuum of increasingly serious interferences with action taken pursuant to religious belief. As Sherbert indicates, the whole distinction between direct and indirect burdens seems only to further hide the factors motivating the Court; much of the difference between the majority and dissent in that case can be explained by observing that the dissent clearly characterized the burden as an indirect one, 374 U.S. at 421, while the majority was unclear on this point. $I d$. at 403-04.

Another difficulty is the lack of clarity to the concept of "available alternative." Apparently it means another mode of regulation which accomplishes the desired end without abandoning the whole legislative program. In most cases this alternative would be the granting of an exemption from the law for those whose free exercise is infringed, but it might also include a complete restructuring of the regulatory scheme.

37 Braunfeld found that there were no alternatives available which would accomplish the state's regulatory purpose. Braunfeld v. Brown, 366 U.S. 599, 608 (1961). The possible 
The doctrinal confusion aside, however, Sherbert appears to be an attempt by the Court to formulate a more stringent standard than that of Braunfeld by which to test the validity of legislation under the free exercise clause in the light of the neutrality theory. ${ }^{38}$ This standard may be formulated as follows: When general regulatory legislation with a secular purpose has the effect of infringing on the free exercise of religion, the state must adopt an alternative form of regulation which eliminates this infringement, unless it can demonstrate that no alternative form of regulation can accomplish the legislative purpose without entailing unreasonable costs. This standard would require that the regulatory scheme be injured by the granting of the religious exemption before the denial of that exemption would be sustained, ${ }^{39}$ on the ground that to avoid the appearance of hostility to religion, the state should have no practical alternative to the denial of the exemption.

Sherbert appears to be the controlling expression of the meaning of the free exercise clause under the neutrality theory. Two observations support this assertion. ${ }^{40}$ First, there is at least some tension between

alternative was the granting of an exemption from the law by allowing sabbatarians to make Sunday sales, as was done in sixty percent of the states which had Sunday laws. Id. at 614. Sherbert, following the same line of reasoning as Braunfeld, found that granting the exemption was not only an available alternative, but a constitutionally compelled one.

For varying views on the relationship of Braunfeld and Sherbert, compare Sherbert v. Verner, 374 U.S. 398, $408-09$ (1963) (Brennan, J.), with id. at 417-18 (Stewart, J., concurring) and id. at 421 (Harlan, J., dissenting). Mr. Justice Douglas maintains that Sherbert overruled Braunfeld. See Solomon v. South Carolina, 382 U.S. 204 (1965).

38 The Court made an attempt to distinguish Braunfeld on its facts on the ground that there the burden was less direct, the state interest greater, and the administrative difficulties insurmountable. Sherbert v. Verner, 374 U.S. 399, 408 (1963). All this is unpersuasive. In the two cases the administrative difficulty which would be encountered by granting the exemption was weighed under different standards, for in Braunfeld the practice of other states in granting the exemption was unimportant, while in Sherbert it was significant. Compare Sherbert v. Verner, 374 U.S. 399, 407 n.7 (1963), with Braunfeld v. Brown, 366 U.S. 599, 608 (1961). Further, degrees of directness and relative strengths of state interests are at best difficult to isolate.

39 See Comment, Religious Accommodation Under Sherbert v. Verner: The Common Sense of the Matter, 10 Vinc. L. REv. 337,339 (1965). The difference in tone and emphasis between the two cases can best be seen by noting that Braunfeld v. Brown, 366 U.S. 599, 608 (1961), seems to require that the claimant demonstrate the practicability of the suggested alternative. Sherbert v. Verner, 374 U.S. 398, 407 (1963), seems to shift the burden of persuasion when it states: "[I]t would plainly be incumbent upon . . . [the state] to demonstrate that no alternative forms of regulation would combat such abuses [as granting the exemption would engender] without infringing on First Amendment rights."

40 It may be significant in this context that Mr. Justice Brennan appears still to adhere 
the result in Sherbert, requiring a religious exemption, and the establishment clause doctrine of Schempp, forbidding actions taken for the purpose of the advancement of religion, for the required exemption seems to have the purpose of aiding the claimant in the practice of her religion.41 This tension would not have been present had the Court in Sherbert followed Braunfeld and denied the exemption. Despite this difficulty, and the recency of Braunfeld, the Court chose not to follow Braunfeld. Second, in the most recent free exercise case, In re Jenison, ${ }^{42}$ the Court chose to rest its decision on Sherbert, rather than Braunfeld, even though both precedents seemed equally persuasive.

Combining Sherbert and the establishment clause cases such as Everson and Schempp, the operative principle under the neutrality theory may be derived. It is perhaps best stated as: "No help, unless no help is harm." 43 That is, while government may neither prefer one religion over another, nor all religions generally, it may not be oblivious to the effects of governmental regulations on religiously motivated activity. Therefore, in order that neutrality not become hostility, governmental action will be required whenever possible to minimize the effect of regulation on a citizen's religious activity. In Schempp, considerations under the establishment clause forbidding preferences controlled, because even with an exemption for the children who did not wish to participate, the state could not insulate an obvious preference for, and espousal of, religion. In Sherbert, on the other hand, the ease of eliminating the burden imposed by the

to his dissent in Braunfeld, though he wrote the opinion of the Court in Sherbert. See Solomon v. South Carolina, 382 U.S. 204 (1965).

41 Sherbert v. Verner, 374 U.S. 398, $413-17$ (1963) (Stewart, J., concurring); id. at 422-23 (Harlan, J., dissenting). The Sherbert majority unconvincingly denies any inconsistency between the decisions by saying that its decision "does not represent that involvement of religious with secular institutions which it is the object of the Establishment Clause to forestall." Id. at 409. Schempp, however, did not involve a religious institution, but a religious practice. The tension is further emphasized in the Court's later statement that it was reaffirming the proposition that a state may not exclude individuals from the benefits of welfare legislation "because of their faith or lack of it." Id. at 410 (quoting from Everson v. Board of Education, 330 U.S. 1, 16 (1947)). South Carolina was not excluding the claimant because of her religion.

42375 U.S. 14 (1963). In a per curiam decision the Court vacated and remanded, for reconsideration in the light of Sherbert, a contempt conviction for refusal, on religious grounds, to serve on a jury. Jenison is both a stronger-no monetary cost to the stateand a weaker-a penal sanction-case than Sherbert for departing from the Braunfeld precedent.

43 Gorman, A Case of Distributive Justice, in ReLigron AND THE Schools 34, 60 (Fund for the Republic 1959). 
regulation on the citizen's religious action was such that under the free exercise clause any refusal to eliminate that burden would express the equally forbidden hostility to some religions. Thus the two cases seem to reflect, if not express, the same principle of neutrality.

Were the Court to adopt the principle of neutrality in its approach to the constitutional claim of the conscientious objector, it would hold that an exemption is required by the first amendment. ${ }^{44}$ If the religious objector were denied the exemption, a burden would be imposed on his free exercise of religion by forcing him to act contrary to his religious beliefs. ${ }^{45}$ To decide whether this is an impermissible burden the neutrality theory begins with the concept of "no help," which would seem to indicate that no exemption should be granted because such an exemption would aid religion by preferring the religious basis for objection to war over other possible bases for objection. The neutrality theory, however, also requires that the conscientious objector exemption be considered under the concept "unless no help would be harm," which would require that this burden be eliminated if there is an available alternative form of regulation.

That the denial of an exemption is not essential to the maintenance of an effective military establishment is indicated in part by the fact that Congress has always exempted the conscientious objector without apparent detriment. The number of conscientious objectors is insignificant-0.065 percent of all registrants. 46 $^{\prime}$ Even more important, statistics show that the percentage of conscientious objector exemptions granted has remained relatively constant since 1948-unaffected by either the Korean or the present Vietnamese war. ${ }^{47}$ This is con-

44 This comment has avoided the historical problems posed by the first amendment as well as the question whether the first amendment was intended to protect conscientious objection. See Freeman, $A$ Remonstrance for Conscience, 106 U. PA. L. REv. 806, 808-13 (1958). Howe, The Garden and THE WrLderness 1-31 (1965), seems, however, to overstate his case when insisting on the relevance of the historical meaning of the clauses for the solution of contemporary problems, for "in the end the Supreme Court is free to give this language the meaning that it chooses .... in accommodating constitutional interpretation to the felt needs of the day." KAUPER, RELIGION AND the Constitution 47 (1964). But see Kelly, Clio and the Court: An Illicit Love Affair, 1965 Sup. Cr. Rev. 119-32, 137-42.

45 There would seem to be little question that this is a burden on free exercise. Part of the practice of these people's religion requires them to refrain from killing even in time of war, a requirement like the distribution of tracts in Murdock v. Pennsylvania, 319 U.S. 105 (1943), or the observance of dietary restrictions. A schema for analysis of these problems is vaguely set out in Sherbert v. Verner, 374 U.S. 398, 403-06 (1963).

$4620,200 / 32,640,000$ (June 30, 1966). Letter and statistics from Kenneth H. McGill, Chief, Research and Statistics Division, Selective Service System, to the University of Chicago Law Review, April 6, 1966, on file in the Review office.

$47 \mathrm{Ibid}$. There have been slight declines at the end of the Korean War, 1952-53, and, curiously, in 1963. 
sistent with our experience in both World Wars, where the war effort was not impaired by the conscientious objector exemption. ${ }^{48}$ Even under the recently broadened exemption it is unlikely that there will be a great rush of claimants. ${ }^{49}$ Furthermore, experience with nonexempt conscientious objectors indicates that their presence in the armed services, or in jail, could be a greater detriment to a war effort than any manpower advantage gained through their conscription. These men will not fight, ${ }^{50}$ and it takes men to guard them in prison; men who could otherwise be fighting. ${ }^{51}$ Arguments against the exemption based on the difficulty of determining sincerity of belief ${ }^{52}$ are undermined by both the British experience with an exemption broader than our own, ${ }^{53}$ and the past success in administering our own law. ${ }^{54}$ Moreover, Sherbert suggests that the simple assertion of the possibility that spurious claims might be made under the exemption is not a sufficient argument to deny the exemption; actual harm must be shown to result from granting the exemption, ${ }^{55}$ and past experience indicates that such a showing could not be made.

All of these considerations indicate that granting the exemption for

48 During World War I the number of claimants was $2.3 \%(64,700)$ of those inducted $(2,810,000)$; only $2.0 \%(56,000)$ however, received the exemption, which gave only noncombatant status. Of these men only $0.74 \%(20,800)$ were inducted and only $0.12 \%$ $(4,000)$ continued their claims once in camp. No figures are available for the total number of registrants. Selective Service System, Conscientious Objection 53 (Special Monograph No. 11, 1950).

In World War II, under a considerably broadened exemption, the number of claimants was $0.55 \%(72,000)$ of those inducted $(13,000,000)$, but only $0.40 \%(52,000)$ received the exemption. Registration was 34,000,000. Id. at 314-15.

49 See United States v. Seeger, 380 U.S. 163, 166 (1965); notes 100-10 infra and accompanying text. The percentage of exemptions granted has undergone no perceptible change since this decision was handed down in March, 1965. Letter from Kenneth H. McGill, supra note 46.

so Of the 15,758 people convicted of violation of the selective service laws during World War II, 6,086 were conscientious objectors, 4,411 of whom were Jehovah's Witnesses. Selective Service System, Conscientious Objection 263 (Special Monograph No. 11, 1950).

b1 Cf. Central Committee for Conscientious Objectors, Handbook for Conscientious ObJectors 85-88 (1953); Selective Service System, Conscientious ObJection 255-57 (Special Monograph No. 11, 1950).

52 Cf. Smith and Bell, The Conscientious Objector Program: A Search for Sincerity, 19 U. PItT. L. Rev. 695 (1958).

53 The exemption was granted to all conscientious objectors regardless of the basis of their belief. National Service Act of 1948, 11 \& 12 Geo. 6, c. 64 \& 17. See Hayes, ThE Challenge of Consclence (1949); Siblex \& Jacob, Conscription of Conscience 2-7 (1952). The exemption was extended to certain limited classes of partly political objectors. HAYEs, op. cit. supra, at 52-64. During the war there were 61,000 claims made, 43,000 granted. Registration was 8,123,000. Id. at 382-83.

54 Selective Service System, Conscientious ObJection 398 (Special Monograph No. 11, 1950).

55 Sherbert v. Verner, 374 U.S. 398, 407 (1963). 
the religiously motivated objector will not impair the defense effort. Granting the exemption is a viable alternative form of regulation, and thus, under the neutrality theory, constitutionally required.

\section{B. The Accommodation Theory}

The accommodation theory of the meaning of the first amendment emphasizes the free exercise clause and narrowly restricts the establishment clause. Its proponents argue that chaplains, governmental mottos, draft exemptions, and religious property exemptions are constitutionally permissible instances of cooperation between church and state in the United States. ${ }^{56}$ Most important to them, however, is Zorach $v$. Clauson, ${ }^{57}$ the one Supreme Court case which may be said to have adopted this theory with its famous dictum: "We are a religious people whose institutions presuppose a Supreme Being."58

In Zorach the Court upheld a program of released time religious instruction much like the program invalidated four years earlier as a violation of the establishment clause in McCollum v. Board of Education.59 Unlike $M c$ Collum, however, the instruction was not given on school property; rather the participating children were released early from school to go to their church for classes. While the McCollum opinion gave no indication that such an alteration in the program would be of any significance, ${ }^{60}$ it turned out to be determinative in Zorach:

When the state encourages religious instruction or cooperates with religious authorities by adjusting the schedule of public events to sectarian needs, it follows the best of our tradition. For it then respects the religious nature of our people and accommodates the public service to their spiritual needs. ${ }^{B 1}$

The case has been distinguished from McCollum in every possible way, but never limited or overruled. ${ }^{62}$ It seems to deviate in tone and approach from the other establishment clause cases. ${ }^{63}$ Thus its force

56 See generally Drinan, Religion, the Courts, and Public Policy (1963); Kauper, REligion AND THE Constitution (1964).

57343 U.S. 306 (1952).

$58 \mathrm{Id}$. at 313.

59333 U.S. 203 (1948).

60 The case seemed to rest on the state's use of the compulsory school attendance mechanism for the benefit of religious groups. Id. at 209. See note 24 supra.

61 Zorach v. Clauson, 343 U.S. 306, 313-14 (1952).

62 See, e.g., School District v. Schempp, 374 U.S. 203, 223, 261-62 (1963), Torcaso v. Watkins, 367 U.S. 488, 494 (1961).

63 See KURLAND, RELIGION AND THE LAW 88-90 (1963). 
as precedent is difficult to determine, though it may be significant that McGowan, ${ }^{64}$ which also rejected an establishment claim, nowhere relied on Zorach. Yet its thesis is not inconsistent with the results in cases like Sherbert and Murdock v. Pennsylvania, ${ }^{65}$ which may be read as requiring accommodations in programs of governmental regulation to minimize interference with religious practice. ${ }^{66}$

The accommodation theory is based on the notion that the religion clauses are essentially directed at the protection of religious liberty. ${ }^{67}$ Therefore, the government must provide a healthy atmosphere for the growth of religion and religious influences on life by allowing a broad scope of constitutionally protected religious activity. To accomplish this end the establishment clause must be read narrowly to forbid only governmental preference among religions and extreme instances of direct support. ${ }^{68}$

Were the Court to adopt the accommodation theory in passing on the constitutional claim of the conscientious objector, it is certain that the claim would be upheld, as the force of the establishment clause limitation would be minimized. Under the doctrine of Zorach and the logic of Sherbert, the government would be required to accommodate the needs of national defense to the religious needs of its people, and provide an exemption for the conscientious objector. This result is strengthened by the facts shown earlier ${ }^{69}$ which indicate that granting the exemption has a negligible effect on the maintenance of national defense.

\section{The Separation Theory}

The separation theory of the meaning of the religion clauses is the opposite of the accommodation theory, for it emphasizes the establishment clause and tends to limit the free exercise clause. It has probably never commanded a majority of the Court.

64 McGowan v. Maryland, 866 U.S. 420 (1961); see text accompanying notes 20-21 supra. 65319 U.S. 105 (1943) (solicitation license tax invalid as applied to distributors of religious tracts).

60 This is how Mr. Justice Stewart, the current defender of the accommodation theory on the Court, views them. Sherbert v. Verner, 374 U.S. 398, 415-16 (1963); School District v. Schempp, 374 U.S. 203, 312-13, 317 (1963).

67 Some of the more extreme versions of the accommodation theory hold that part of the idea of religious liberty is toleration by the minority of the non-coercive practices instituted by the majority. Griswold, Absolute Is in the Dark: $A$ Discussion of the Approach of the Supreme Court to Constitutional Questions, 8 UTAF L. REv. 167 (1963).

68 For example, such support might take the form of payments for the furtherance of purely religious purposes such as guaranteeing loans on church buildings or providing money for the purchase of hymnals.

69 See text accompanying notes 46-54 supra. 
The dissent of Mr. Justice Rutledge in Everson v. Board of Education, $^{70}$ the school transportation payments case, is the most famous judicial statement of the theory. There he declared: "The great condition of religious liberty is that it be maintained free from sustenance, as also from other interferences, by the state." 71 Thus the establishment clause "forbids state support, financial or other, of religion in any guise, form or degree. It outlaws all use of public funds for religious purposes."72

While the adherents of the separation theory agree that this is the meaning of the establishment clause, they differ as to the meaning of the free exercise clause, so that two distinct separation theories may be isolated. These two theories emerge most clearly through a comparison of the positions taken by the Everson dissenters in the earlier decision of Murdock v. Pennsylvania. ${ }^{73}$ There the Court granted an exemption for religious solicitation from a general solicitation license tax. Mr. Justice Rutledge joined in the Court's opinion, which stressed that the tax was a burden on the constitutional right of free exercise of religion, and denied that the decision created a subsidy of religion forbidden by the establishment clause. ${ }^{74}$ However, Justices Frankfurter and Jackson argued that separation required a different result, and dissented here also. They reasoned that by granting the exemption the Court sanctioned a forbidden subsidy of religion by relieving a citizen from the burden of a general tax solely because of his religious beliefs. ${ }^{75}$ Justice Rutledge's position produces a separation theory which would prohibit governmental spending, the benefit of which inures to any religious organization; it likewise would prohibit interference with the religiously motivated action of an individual. ${ }^{78}$ On the other hand,

70330 U.S. I, 28 (1947). Justices Frankfurter, Jackson and Burton joined in the opinion. $71 \mathrm{Id}$. at 53 .

$72 \mathrm{Id}$. at 39.

73319 U.S. 105 (1943) (Douglas, J.). See Follett v. Town of McCormick, 321 U.S. 573 (1944) (Douglas, J.) (a similar situation and result as in Murdock except that the appellant this time earned his living selling these religious tracts).

74 Murdock v. Pennsylvania, 319 U.S. 105, 112 (1943). See Follett v. Town of McCormick, 321 U.S. 573, 577-78 (1944).

75 Murdock v. Pennsylvania, 319 U.S. 105, 135, $139-40$ (1943) (Frankfurter, J.). See Follett v. Town of McCormick, 321 U.S. 573, 580-81, 583 (1944) (separate opinion of Roberts, Frankfurter, and Jackson, JJ.). Mr. Justice Burton, the fourth dissenter in Everson, was not on the Court when Follett or Murdock were decided.

The issue separating these two versions of the separation theory is explored, though not joined, by the concurring opinion of Mr. Justice Murphy and the dissenting opinions of Justices Roberts, Frankfurter, and Jackson in Follett v. Town of McCormick, 321 U.S. 573, 578-79, 579-88 (1944). The difference appears to be solely whether exemptions offend the establishment clause to the extent that direct payments do.

78 This is the position of Mr. Justice Douglas today. See generally his opinions in Sherbert v. Verner, 374 U.S. 398, 410 (1963) (concurring); School District v. Schempp, 374 
the position of Justices Frankfurter and Jackson produces a separation theory which would prohibit governmental support of religion, as well as the granting of special considerations to the religious citizen. ${ }^{77}$

Were the Court to follow the Rutledge interpretation of the separation theory, it is fairly apparent that the constitutional claim of the conscientious objector would be upheld. Mr. Justice Douglas, the current proponent of this theory on the Court, suggested that this was the proper result in his concurrence in United States $v$. Seeger, ${ }^{78}$ a recent case which construed the present statutory exemption. There he adverted to a possible violation of the free exercise clause were the Court to deny the claimant an exemption, ${ }^{79}$ and cited Sherbert as the applicable precedent. ${ }^{80}$ His reasoning seems to be that since the exemption neither requires the expenditure of government funds, nor results in promoting religion through official sanction in the manner of Schempp, the exemption must be granted as in Murdock and Sherbert to keep from interfering with free exercise. ${ }^{81}$ It is equally apparent that the Frankfurter-Jackson approach would deny the conscientious objector's claim, for this position allows no constitutionally compelled religious exemptions in general legislation.

\section{The Kurland Theory}

As the previous discussion indicates, the various theories of the religion clauses all suffer from a fragmented approach which makes it difficult to state a coherent doctrine. Professor Kurland has sought to remedy this difficulty and to state a unifying principle:

U.S. 203, 227 (1963) (concurring); Engel v. Vitale, 370 U.S. 421, 437 (1962) (concurring); McGowan v. Maryland, 366 U.S. 420, 561 (1961) (dissenting). He has indicated that he now feels that his vote with the majority in Everson v. Board of Education, 330 U.S. 1 (1947) was wrong. Engel v. Vitale, 370 U.S. 421, 443-44 (1962). He wrote the opinions in Follett and Murdock. His majority opinion in Zorach v. Clauson, 343 U.S. 306 (1952) is not inconsistent with his position in these cases.

The difference between his version of the separation theory and the neutrality theory is that he finds that there can never be a secular purpose to expenditures which inure to the benefit of religious institutions, while the neutrality theory recognizes that some such expenditures, for example the bus transportation in Everson, can have a secular purpose.

77 No member of the current Court apparently holds this position. The only possible candidates would be Justices Harlan and White, the dissenters in Sherbert v. Verner, 374 U.S. 398 (1963). Their dissent in that case, as well as their votes in Schempp, indicate that they adhere to variants of other theories of the religion clauses.

78380 U.S. 163 (1965).

$79 I d$, at 188.

80 He dissented in the case of Braunfeld v. Brown, 366 U.S. 599 (1961), in an opinion accompanying McGowan v. Maryland, 366 U.S. 420, 561 (1962).

81 But see Prince v. Massachusetts, 321 U.S. 158 (1944) (religious duty no defense to child labor law violation) (Opinion by Rutledge, J., joined by Douglas, J.). This vote is clearly out of line with his position today. 
[T] he proper construction of the religion clauses of the first amendment is that the freedom and separation clauses should be read together as a single precept that government cannot utilize religion as a standard for action or inaction because these clauses prohibit classification in terms of religion either to confer a benefit or to impose a burden. ${ }^{82}$

This suggestion has not received universal acclaim. ${ }^{83}$ Some of the members of the Court have commented on it, but none have accepted it. ${ }^{84}$ In fact, all the Justices may be said to have rejected this thesis in Sherbert $v$. Verner, ${ }^{85}$ for the result of that case required that a benefit-unemployment compensation-be extended to the claimant on the basis of a religious classification.

Professor Kurland's theory has some support in the cases, especially Everson, McCollum, and Torcaso v. Watkins. ${ }^{86}$ These establishment clause cases have led two commentators to maintain that the conscientious objector exemption, at least as currently written, is unconstitutional. ${ }^{87}$ Professor Kurland indicates that he would agree with this analysis but for the possibility of the continued vitality of the Selective Draft Law Cases, ${ }^{88}$ which sustained the conscientious objector exemption from attack on establishment grounds. These cases he implies were

82 KuRLAND, ReLigion ANd the LAw 18 (1962). The Frankfurter-Jackson version of the separation theory may be identical to the theory of Professor Kurland. Whether this is so depends on their decision in a type of case they never had a chance to decide; the state-granted exemption such as the religious property tax exemption. The Kuxland theory would find this unconstitutional, assuming that the exemption did not extend to all eleemosynary bodies; it is not clear what Mr. Justice Frankfurter would have done. See McGowan v. Maryland, 366 U.S. 420, 520-22 (1961); McCollum v. Board of Education, 333 U.S. 203, 227 (1948). But cf. Heisey v. County of Alameda, 352 U.S. 921 (1956) (dissent from per curiam dismissal for want of substantial federal question of a religious tax exemption case).

83 See, e.g., Pfeffer, Religion Blind Government, I5 Sran. L. REv. 389 (1963); Kauper, Book Review, 41 TEXAS L. REv. 467 (1963).

84 Sherbert v. Verner, 374 U.S. 398, 422 (1963) (Harlan, J., dissenting); School District v. Schempp, 374 U.S. 203, 296 n.70 (1963) (Brennan, J., concurring).

85374 U.S. 398 (1963). While the result which the dissenters advocate, denial of the exemption, is consistent with the Kurland thesis, they explicitly reject that thesis. Id. at 422

86367 U.S. 488 (1961) (state constitutional requirement that public officers swear to the belief in the existence of God invalid). It is clear, however, that the author of these opinions, Mr. Justice Black, would not extend their rationale to the free exercise clause as would Professor Kurland. See, e.g., Sherbert v. Verner, 374 U.S. 398 (1963); Murdock v. Pennsylvania, 319 U.S. 105 (1943); where Mr. Justice Black voted to grant exemptions clearly forbidden by the Kurland theory on free exercise grounds.

87 Donnici, Govermment Encouragement of Religious Ideology: A Study of the Current Conscientious Objector Exemptions From Military Service, 13 J. PUB. L. 16 (1964); Conklin, Conscientious Objector Provisions: $A$ View in the Light of Torcaso v. Watkins, 51 GEO. L.J. 252 (1968).

88245 U.S. 366 (1918). 
wrongly decided. ${ }^{89}$ Under the Kurland theory, if the conscientious objector is to have his beliefs respected, the draft must either be abandoned and service be made voluntary, or a rational classification must be found which includes the objector without being based on a religious standard. Thus, application of the Kurland theory by the Court would lead to the rejection of the conscientious objector's claim under the free exercise clause.

This attempt to explore the various major theories of the religion clauses has demonstrated that the neutrality, accommodation, and Rutledge version of separation theories support a constitutional claim to the conscientious objector exemption. The Frankfurter-Jackson and Kurland theories do not. Which one the Court will adopt, if it meets the question, is unclear. However, the voting records, as well as the theories articulated by a majority of the current Court, indicate that the exemption would be constitutionally required.90

\section{The Scope of the Conscientious Objector Exemption}

In attempting to establish that the conscientious objector exemption is constitutionally required, it has been assumed that the scope of the exemption is settled law and includes all people who might properly be called religious objectors. In view of the general uncertainty in the law of the religion clauses, this assumption warrants examination. Such examination indicates the extreme difficulty of determining the current constitutional definition of religion, ${ }^{91}$ as well as whether an exemption which extends only to the religious objector is constitutionally sufficient. ${ }^{92}$ It also casts some light on the instability and latent internal inconsistency observable in all of the theories of the religion clauses.

When the religion clauses are viewed separately, the conceptual con-

89 KurLAND, ReLigion and the LAw 40-41 (1962).

90 See notes 66, 76, \& 77, and text accompanying note 85 supra. Justices Harlan and White might even switch their votes if they felt Sherbert was a sufficiently strong precedent, and felt bound by it.

91 For an attempt at this task see Comment, Defining Religion: Of God, the Constitution, and the D.A.R., 32 U. CHr. L. REv. 533 (1965).

92 While this comment will deal with the question of the necessary scope of the conscientious objector exemption under the assumption that the exemption is constitutionally required by the free exercise clause, the need for this inquiry arises regardless of whether the exemption is constitutionally required. Under the doctrine of unconstitutional conditions an exemption which was only a matter of legislative grace could not be granted arbitrarily but would still be subject to the applicable constitutional requirements. See Speiser v. Randall, 357 U.S. 513 (1958); Bolling v. Sharp, 347 U.S. 497 (1954); American Communications Ass'n v. Douds, 339 U.S. 382, 417 (1950) (opinion of Frankfurter, J.); French, Unconstitutional Conditions: An Analysis, 50 GEo. L.J. 234 (1961); Comment, Unconstitutional Conditions, 73 HARv. L. REv. 1595 (1960). Among these requirements would be the standards of the religion clauses. 
flict between them, on which Mr. Justice Stewart commented in Sherbert, ${ }^{93}$ becomes apparent. The majority opinion in Schemp $p,{ }^{94}$ resting on the purpose and effect of the law in question, may be viewed as a restatement of the doctrine of Everson ${ }^{95}$ and Torcaso, ${ }^{96}$ which is that the establishment clause forbids governmental preference, both as to benefits and burdens, either among believerstheist and nontheist alike-or between believers and nonbelievers. ${ }^{97}$ Under this interpretation of the establishment clause, the conscientious objector exemption may not be granted on a religious standard, for to do so would be to prefer believers over nonbelievers. However, the free exercise cases, especially Sherbert ${ }^{98}$ and Murdock, ${ }^{99}$ may be read to require special privileges and exemptions for the religious personspecifically the conscientious objector exemption. Thus follows the curious result that an exemption for the religious objector seems to be prohibited by the establishment clause and at the same time required by the free exercise clause.

93 Sherbert v. Verner, 374 U.S. 398, 414, 416 (1963). See also School District v. Schempp, 374 U.S. 203, 309 (1963) (Stewart, J., dissenting). Mr. Justice Harlan also noted the conflict in his dissent in Sherbert. 374 U.S. at 422-23. The majority of the Court, however, will not admit that its reading of the clauses results in a conflict; at the most the clauses "overlap." See School District v. Schempp, 374 U.S. 203, 222 (1963); Engel v. Vitale, 370 U.S. 421 , 430 (1962).

94 School District v. Schempp, 374 U.S. 203 (1963); see text accompanying notes 19 \& 25 supra.

95 Everson v. Board of Education, 330 U.S. 1, 15 (1947); see note 23 supra and accompanying text.

96 Torcaso v. Watkins, 367 U.S. 488, 495 (1962); see note 24 supra.

97 "Neither [a state nor the federal government] can constitutionally pass laws or impose requirements which aid all religions as against non-believers and neither can aid those religions based on a belief in the existence of God as against those religions founded on different beliefs." Torcaso v. Watkins, 367 U.S. 488, 498 (1961). Thus, the purpose and effect language of Schempp and McGowan is disregarded. See text accompanying notes 19-24 supra. The result appears to be much like the theory of Professor Kurland, except that contrary to his approach the principle is applied only to the establishment clause.

It is apparent from the above language that there are three groups of people about whom the Court is concerned in religion clause cases-the theists, believing in the existence of God; the nontheists, believing in some ultimate, but not in the existence of God; and the nonbelievers, at least the atheists, adherents to various philosophical systems, and those with no system of beliefs. Exactly who falls in these groups is not clear however. This comment has assumed that the Court considers all those people who fall within the rule of United States v. Seeger, 380 U.S. 163, 165-66 (1965) (quoted at note 110 infra), to completely fill the theist and nontheist categories, and that this grouping is coextensive with the current constitutional meaning of "religion." But see Rabin, When Is a Religious Belief Religious: United States $v$. Seeger and the Scope of Free Exercise, 51 CoRNELI L.Q. 231, 242-44 (1966); Comment, supra note 91, 32 U. CHI. L. REv. at 537 n.24 (1965).

98 Sherbert v. Verner, 374 U.S. 398, 406-07 (1963); see text accompanying notes 26-30 supra.

99 Murdock v. Pennsylvania, 319 U.S. 105 (1943); see text accompanying notes 73-75 supra. 
An examination of the recent case of United States $v$. Seeger ${ }^{\mathbf{1 0 0}}$ helps to illuminate the logical difficulty at the core of this conflict. Seeger asserted "that his was a belief in and a devotion to goodness and virtue for their own sakes, and a religious faith in a purely ethical creed." 101 While admitting his sincerity, his draft board denied him a conscientious objector exemption solely because his opposition was not based upon a belief "in a relation to a Supreme Being" as required by the statute. ${ }^{102}$ As thus applied to Seeger, a nontheist, ${ }^{103}$ the statutory language and intent seemed to violate both the establishment clause, by preferring theists over nontheists, ${ }^{104}$ and the free exercise clause, by denying the nontheists the free exercise of their religion. ${ }^{105}$ The trial court rejected these arguments and Seeger was convicted of refusing to submit to induction. ${ }^{106}$ That conviction, however, was reversed on appeal, ${ }^{107}$ and the Supreme Court affirmed. ${ }^{108}$ But, by adopting a broad construction of the "Supreme Being" clause,"102 the Court was able to avoid all of the serious constitutional issues:

[T] he test of a belief "in a relation to a Supreme Being" is whether a belief that is sincere and meaningful occupies a place in the life of its possessor parallel to that filled by the orthodox belief in God of one who clearly qualifies for the exemption. ${ }^{110}$

100380 U.S. 163 (1965).

101 United States v. Seeger, 326 F.2d 846, 848 (2d Cir. 1964).

102 Universal Military Training and Service Act, 62 Stat. 613 (1948), 50 U.S.C. App. $\S 456(j)$ (1964).

103 Throughout the proceedings Seeger maintained that he was a religious objector. Brief for Respondent, pp. 3-4, 21, 28-31, 41. The Government strongly denied this. Reply Brief for the United States, pp. 1-3.

104 See United States v. Seeger, 326 F.2d 846, $851-53$ (2d Cir. 1964); United States v. Jakobson, 325 F.2d 409, 414 (2d Cir. 1963).

105 See United States v. Seeger, 326 F.2d 846, 852-53 (2d Cir. 1964); United States v. Jakobson, 325 F.2d 409, 415 (2d Cir. 1963).

108 United States v. Seeger, 216 F. Supp. 516 (S.D.N.Y. 1964).

107 United States v. Seeger, 326 F.2d 846 (2d Cir. 1964).

108 United States v. Seeger, 380 U.S. 163 (1965).

109 The construction adopted was supported by neither the text nor the legislative history. See S. REP. No. 1268, 80th Cong., 2d Sess. 14 (1948); Comment, Conscientious Objector Exemption: Still Unsettled, 33 GEo. WASH. L. REv. 1108 (1965); Comment, supra note 91, 32 U. CHI. L. REv. 533.

110 United States v. Seeger, 380 U.S. 163, 165-66. This test was first stated in Fellowship of Humanity v. County of Alameda, 153 Cal. App. 2d 673, 679, 315 P.2d 394, 406 (Dist. Ct. App. 1957). Just who is included and who is excluded under this formulation is by no means clear. The rule is seemingly limitlessly expansive and could be said to include a belief in personal survival as the ultimate good, a belief it is doubtful the Court intended to encompass in the class of those people exempted. For a further exploration of the difficulties caused by the indeterminacy of the limits of the Seeger test, see authorities cited note 115 infra. 
This careful work, of course, has not begun to solve the many constitutional problems raised by an inquiry into the necessary scope of the conscientious objector exemption. For example, granting the exemption only to the religious objector, and thus denying the exemption to the sincere objector who disclaims any religious basis to his objection and who thus has no claim under the free exercise clause, can be said to violate the establishment clause by preferring all religious persons over nonbelievers. ${ }^{111}$ Yet, it has been assumed that the free exercise clause requires this exemption for the religious objector. Thus, while in the case of the religious objector, Seeger, the two clauses were both violated and worked together to secure an exemption, with the nonreligious objector the clauses are not working harmoniously, but lead to conflicting results. Since the only factor which has been changed in the two situations is the status of the claimant, that must reflect the cause of the conflict between the clauses.

The reason why the change in the status of the claimant results in exposing the conflict is that the clauses vary as to the groups of people which they protect. The free exercise clause as currently interpreted considers governmental action only with respect to believers-nontheists as well as theists. ${ }^{112}$ In contrast, the establishment clause as currently interpreted considers governmental action with respect to three groups-the two groups of believers, and the nonbelievers as well.113 Thus the necessity of adjusting state action with respect to the

111 See authorities cited note 87 supra.

112 See School District v. Schempp, 374 U.S. 203, 222-23 (1963); Braunfeld v. Brown, 366 U.S. 599, 603-06 (1961).

Torcaso v. Watkins, 367 U.S. 488, 495 (1962) (Maryland Constitutional provision requiring public officers to swear to their belief in God invalid), may indicate to the contrary, for the Court was unclear as to whether it was deciding that case under the establishment clause or the free exercise clause. The case is usually considered an establishment case. See School District v. Schempp, supra, at 216, 220. But see Douglas, THE Bible AND THE Schools 9 (1966). Except for the matter of appropriate remedy, it makes no difference which kind of case it was as long as the Court considered the claimant to be one of the nontheists, for then the case is just like Seeger. If, however, he was considered to be one of the nonbelievers, and the case was decided on free exercise grounds, then the conflict may thus have been eliminated through expansion of the free exercise clause to include nonbelievers. See note 114 infra.

For a short discussion of the classification of "believers" and "nonbelievers" see note 97 supra. The Seeger opinion seems to accept this system of classification, although the Court makes no attempt to give the terms any great degree of precision.

113 See Torcaso v. Watkins, 367 U.S. 488, 495 (1962); Everson v. Board of Education, 330 U.S. 1, 15-16 (1947).

There is a possible explanation for the difference in the scope of the two clauses other than the fact that somehow the Court got started this way and has continued due to the pressure of ways of thought generated by precedent; there would seem to be little reason why a clause guaranteeing the free exercise of religion should include within its protection those who by definition are nonreligious. 
third group-the nonbelievers-to satisfy the establishment clause causes the conflict between the clauses.

Until this conflict is eliminated, it will be difficult to determine the constitutionally necessary scope of the conscientious objector exemption. ${ }^{114}$ Whether it must, under the establishment clause, extend to the nonreligious person is unclear, though Seeger indicates that at the least the exemption must extend to all religious objectors. Yet, without even considering the problems of the Seeger test, ${ }^{115}$ the conflict also makes unclear who is the religious objector, since it casts doubt on the sufficiency of the current case law on which such a definition would necessarily be built.116

Recognition of this conflict also helps to explain both the impetus for the formulation of the various theories of the religion clauses and

114 Several possible resolutions of the conflict between the clauses are open to the Court. The scope of the establishment clause might be limited to forbidding preferences among religions as Mr. Justice Stewart has suggested in Sherbert v. Verner, 374 U.S. 398, 415-16 (1963); this would leave the scope of the conscientious objector exemption as it is now. Alternatively, the scope of the free exercise clause, and correspondingly the exemption, may be expanded to include nonreligious beliefs. A third possibility derives from certain language in Sherbert which indicates that the establishment clause limitations may not operate when exemptions are granted in general regulatory programs on grounds of free exercise. Sherbert v. Verner, 374 U.S. 398, 409 (1963). In this case the exemption need only cover the more narrowly religious objectors. The Court's treatment of the conflict in Seeger suggests a fourth possibility; it may continue to ignore the conflict in which case the exemption will extend to the unclear, indeterminate group delineated by the test in that opinion-the theists, nontheists, and any chameleonic claimant who can appear sufficiently like the others. Either of the last two choices seem the more probable, since the scope of the establishment clause seems well established, and it is hard to maintain that the protection of the free exercise clause, specifically given to the religious person, extends to those who are by definition not religious.

Some of the commentators mysteriously believe that an explanation of the cases will make the conflict disappear. See Moore, The Supreme Court and the Relationship Between the Establishment and Free Exercise Clauses, 42 TExAs L. REv. 142 (1963); Comment, The Free Exercise and Establishment Clauses: Coordination or Conflict?, 48 MiNN. L. REv. 929 (1964).

115 These problems are explored in Brodie \&: Southerland, Conscience, the Constitution and the Supreme Court: The Riddle of United States v. Seeger, 1966 WIsc. L. REv. 306, 316-19 (1966); Comment, Conscientious Objector Exemption: Still Unsettled, 33 GEO. WASH. L. Rev. 1108 (1965); Note, 34 Fordham L. Rev. 129 (1965); Note, 18 VAND. L. Rev. 1564 (1965).

116 It is at least possible that any definition of "religion" is constitutionally impermissible as both an establishment, and a denial of free exercise to anyone mistakenly not included. See Weiss, Privilege, Posture, and Protection: "Religion" in the Law, 73 Yale L.J. 593, 604 (1964). Cf. Cantwell v. Connecticut, 310 U.S. 296, 307 (1940): "[T]o condition the solicitation of aid for religion ... . upon a license, the grant of which rests in the exercise of a determination by a state authority as to what is a religious cause, is to lay a forbidden burden upon the exercise of liberty protected by the Constitution." A strong case can also be made for the inclusion of some of the nonbelievers within the concept of religion. See Rabin, supra note 97 , at 245-47. 
their failure as solutions to the conflict. ${ }^{117}$ Each theory attempts to avoid completely the difficulties created by the conflict through the use of an overriding principle. ${ }^{118}$ All except Professor Kurland's theory accomplish this by disregarding the different logical groupings covered by the clauses, and thus only paper-over the problem created by the scopes of the two clauses. ${ }^{119}$

In the absence of a clear constitutional standard defining the necessary scope of the conscientious objector exemption, the formulation of an exemption which could bypass the constitutional difficulties would seem to provide an acceptable political solution to the problem. It is submitted that the current exemption should therefore be expanded by Congress to include all persons who hold a sincere opposition to participation in war without regard to religious belief. ${ }^{120}$

117 Admittedly, perception of the doctrinal conflict detracts from any conclusion that an exemption is constitutionally required, since that conclusion is based on theories whose soundness is challenged because they do not meet and deal with the conflict. However, either of the solutions to the conflict which have been suggested as most likely to be adopted by the Court, see note 114 supra, would not disturb the analysis used to establish any constitutional requirement.

118 Cf. Katz, Freedom of Religion and State Neutrality, 20 U. CHr. L. REv. 426, 428 (1953); Kauper, Prayer, Public Schools, and the Supreme Court, 61 MICF. L. REv. 1031, 1054 (1963).

119 The neutrality theory conveniently forgets that "no help" may well be "harm," as well as that exemptions granted because of "actual harm" are indeed "help." Likewise, the accommodation theory conveniently forgets that a prohibition of laws "respecting an establishment of religion" is of a tenor contrary to the beneficient cooperation it envisions. The separation theory, on the other hand, forgets that real separation may require the infringement of someone's free exercise. Yet Professor Kurland's theory ultimately avoids the conflict also, for it simply rejects the case law which yields the problem.

120 Where any right under the free exercise clause has at least been tentatively established, the approach to religion clause problems taken in this comment may, as a policy matter, be an acceptable political solution, at least until the Court clears up religion clause doctrine sufficiently to give better guidance than at the present. The technique is simple; if at all possible the legislature should expand the claimed religious exemption to include others similiarly situated without regard to religious belief. It must also be admitted, however, that the possibility of Congress adopting the suggested solution in the case of the conscientious objector is minimal in this wartime climate; adoption of the more general solution is even more problematical.

It may be objected that in the case of the conscientious objector exemption the suggested general approach is exactly the one which the Supreme Court followed in Seeger, and that thus the solution advocated here has already been reached. See Rabin, supra note 97, at 242-44, 247-48; Comment, supra note 91, 32 U. Cre. L. REv. at 550-54 (1965). This argument is, however, questionable. Both the Court and Mr. Justice Douglas stated that the case of an atheist is a different one which they did not decide. United States v. Seeger, 380 U.S. 163, 174-75, 193 (1965). They also iterated that they were extending the exemption only to religious objectors. Id. at 165, 173. But cf. Fleming v. United States, 344 F.2d 912 (10th Cir. 1965), where the court read the statutory exclusion of "essentially political, sociological, or philosophical views" narrowly, saying that it operates only when beliefs falling within it are the only basis for the claimant's exemption. In this process the court was following 
Certain benefits may be derived from expanding the exemption. Most important, the broadened exemption is free from constitutional infirmities under any theory of the religion clauses. The scope of the exemption easily includes the religious objector, as it must under the neutrality, accommodation and Rutledge separation theories. Moreover, since the exemption results in neither support of religion as such nor in the granting of special considerations to the religious citizen, it does not offend the Frankfurter-Jackson analysis. Because it is a rational classification not in terms of religion, it satisfies Professor Kurland's standard.

Second, expansion of the exemption is consonant with the usual analysis of the political problem posed by conscientious objection. Traditionally, two limits have been placed on dissent from the decision to wage war: an individual must oppose participation in all wars and

the Supreme Court's similar treatment of the exclusion of "a merely personal moral code" in Seeger.

It is conceivable that constitutional doctrine could be developed to secure the broader exemption. There are two possible approaches: the due process clause, following the schema of reasoning used in Seeger v. United States, 326 F.2d 846 (2d Cir. 1964), and relying heavily on the psychological similarity between the beliefs of the religious and the nonreligious objector (see authorities cited note 125 infra); or the first amendment generally, following the approach of Board of Education v. Barnette, 319 U.S. 624 (1943) (compulsory flag salute in public schools unconstitutional), and relying on a concept of freedom of belief. An extremely fine use of the constitutional scalpel could give the same result, and perhaps avoid some of the political hassle. The Universal Military Training and Service Act, ch. 149, § 5, 65 Stat. 88 (1951), has separability provisions. By a highly selective use of these provisions the Court could strike out the phrase "by reason of religious training and belief" and the sentence defining it as being violations of the establishment clause in the hope that Congress would not try to eliminate the remainder out of respect to the traditional objectors.

One of the reasons for establishing a constitutional basis for the exemption would be to protect it from congressional tampering as part of an attempt to silence dissent from its policies in a situation when no crisis, which would otherwise justify the action, was imminent. Such a threat is not unreal, as witnessed by the recent congressional response to the draft card burning protests against the war in Viet Nam. The Act of August 30, 1965, 79 Stat. 586 (1965) makes criminal the "knowing destruction or knowing mutilation" of a draft card, which crime is punishable by a five year prison sentence, or a $\$ 10,000$ fine, or both. An examination of the legislative history of the act, 111 Cong. Rec. 19012, 19134-36 (daily ed. Aug. 10, 1965); H.R. REP. No. 747, 89th Cong., 1st Sess. (1965), indicates that the congressional intent, if any, was to express its displeasure with the youthful opponents of the war.

An argument against giving the broader exemption constitutional status based on a supposed necessity to draw on the larger group of conscientious objectors in an extreme crisis somewhat neglects the realities of the situation it envisions. It is questionable whether, given the emergency suggested, there would be any functioning legal process either to inhibit the abrogation of any exemption, even if constitutionally based, or to enforce a revocation, to the extent the exemption might be a matter of legislative grace. Thus the situation of extreme crisis is not that relevant to any balancing of interests involved in determining constitutional status. 
his opposition must be religiously based. ${ }^{121}$ These limitations on individual dissent from political decisions are designed to preserve the government's political integrity by insuring that the individual is not making the same type of political decisions as his government except in the context of the political process maintained to resolve political disagreements of members of that community. ${ }^{122}$ Although it abandons one of the traditional limits on dissent, the suggested exemption continues to provide for preservation of governmental political integrity by retaining the limit more relevant to the political purpose of such limits-the requirement that opposition be to participation in all wars. This limit is the more relevant one because the decision to oppose a particular war in contrast to war in general, is arrived at by reweighing the same factors which impressed themselves on the government in its original decision to wage a particular war. ${ }^{123}$ This is the very process

121 For extended discussions of the place of conscientious objection in political theory see Kellogg, The Conscientrous Objector 121-26 (1919); Laski, Authority in the Modern State 42-52 (1919); Thomas, The Conscientious ObJector in AMrrica 1-13 (1923); Dickinson, Social Order and Political Authority II, 23 Am. PoL. Sar. Rev. 593, 629-30 (1929); Rudlin, Political Obedience, in 11 Encyc. Soc. Scr. 415 (1933). See generally Bosanquet, The Philosophical Theory of the State (1899); Green, Lectures on the Principles of Political Obligation (1895); Hobhouse, The Metaphysical Theory of the State (1918); MiLl, ON LiBerTy (1859).

122 This point reflects the pervasiveness of contract notions in political theory. The social contract, like any contract, is one founded on the reasonable expectations of the parties. It is reasonable for a nation state to require that its citizens refrain from making decisions which reflect on its political integrity in the community of states in exchange for some protection from the other members of that community. A somewhat less conservative version of social contract theory, more applicable to a democracy, would view the contract as between the citizens of the state, whereby the quid pro quo for a stable social and political community is respect for the integrity of the institutional democratic process which arrives at the policy decisions that are being followed. Thus, each citizen must give up his right to make these policy decisions individually in the interest of maintaining the peaceful framework which any community needs to continue to exist as such. This second theory can also be seen as a contract subsidiary to the one between the state and the citizen regulating how state policy shall be determined. These rather simplistic formulations of course must be modified still further in the United States to account for such phenomena as supposedly inviolable minority rights and civil disobedience.

123 It may be objected that a decision by a nation not to oppose the waging of war is the logical premise to a decision to wage any particular war, and that the objector is thus still making the same political choice as the government. Except for the case of historic neutrals such as Switzerland, it is doubtful whether the choice of whether or not to wage any wars can seriously be said to have been squarely made by any nation, logically necessary though it may be, at least in the way the decision to wage or not wage a particular war is made. The element of conscious choice would seem to be a sufficient distinction of the two kinds of decision respecting war generally for the purpose of this discussion. Contract notions again explain this point well. It is the reasonable expectation of the parties to this social contract that the nation state will in the course of time wage some wars, so that the proffered logical premise does not represent a decision open to the state but rather a basic assumption of the parties. 
which limits on dissent are designed to preclude. The religious limitation does not serve the same primarily political function as the "war in general" limitation. It is designed to ease the administration of the law by providing additional evidence that an individual's decision is not an essentially political one, ${ }^{124}$ and therefore may be more easily eliminated without substantially affecting governmental integrity.

Third, expansion of the conscientious objector exemption would result in a fairer draft law: essentially nonpolitical opposition to participation in all wars may have many bases; it need not necessarily be derived from a religious belief. ${ }^{125}$ Most, if not all, of the possible bases for an objection to participation in all wars pose the same type of challenge to governmental authority. ${ }^{126} \mathrm{~A}$ religiously based opposition to war is extremely difficult to distinguish functionally from an objection based on philosophical or ethical grounds. ${ }^{127}$ This difficulty results in the making of somewhat arbitrary distinctions along the exceedingly hazy perimeter of the concept of religious belief. The Seeger case accentuates the arbitrary marginal decisions through the additional vagueness induced by the Court's attempt to be fairer than previously to certain groups who are arguably religious. In view of the similarity of the psychological function of the various bases for opposition to all wars, it would seem desirable to extend the fairness rationale of Seeger by eliminating the religious limitation on the conscientious objector exemption.

The costs in terms of loss of manpower for the defense effort which would be incurred by eliminating the religious limitation appear to be low. First, the number of men who would be exempted would not be a

124 It may be suggested that in addition to deference to religious views and prejudice against the nonreligious, the historical reason for the limitation is the fact that the traditional religious objector's claim to be obeying the command of a non-temporal sovereign provides necessary assurance to the temporal sovereign that his authority was not challenged by granting the exemption.

125 See Boisen, The Conscientious Objectors, 7 PsychiaTry 215 (1944); Kelley \& Johnson, Emotional Traits in Pacifists, $28 \mathrm{~J}$. Social Psychology 275 (1948); Pescor, A Study of Selective Service Violators, 105 American J. of Psychiatry 641 (1949); Schmidt, SocioPsychological Inquiry Into the Nature of Conscientious Objectors as Personalities, June 1946 (unpublished thesis in University of Chicago Library); Shifrin, Personality Patterns of Conscientious Objectors, March 1947 (unpublished thesis in University of Chicago Library).

126 One kind of objector who might be thought to pose a greater challenge would be the radical socialist pacifist who refuses to fight because war is a tool of the capitalists.

127 Clancy \& Weiss, Conscientious Objector Exemptions: Problems in Conceptual Clarity and Constitutional Considerations, 17 ME. L. REv. 143 (1965); Pescor, op. cit. supra note 125; Schmidt, op. cit. supra note 125. The real diffculty of this attempt may be seen from the rather murky results of what is apparently an attempt at making this distinction. Mansfield, Conscientious Objection-1964 Term, 1965 Religion AND the Public Order 1, 12-35. 
significant inroad on the potential manpower available. ${ }^{128}$ The number of objectors in Britain during World War II, under a similar exemption, ${ }^{129}$ was less than 0.5 percent of the number of registrants. ${ }^{130}$ This incidence of objection by no means crippled the British war effort. It would be unlikely seriously to hamper an American effort either. There would need to be an eight-fold increase in the rate of objection in the United States before it even reached the British level; it is hard to believe that there are this many nonreligious objectors waiting for a chance to claim the exemption..$^{131}$ Further, as part of the statutory requirement that objectors perform some work of national importance in lieu of military service, ${ }^{132}$ objectors could be utilized in civilian capacities, thereby freeing some men for service in the armed forces. By not granting the nonreligious person the exemption, the defense effort loses the manpower which would thus be freed.

Second, resting the decision to grant the exemption solely on the determination of the claimant's sincerity should not impose a crippling administrative burden on the Selective Service System, nor should it result in recognizing a great number of fraudulent claims. The present exemption requires a determination of the claimant's sincerity as well as of the religious nature of his belief. The suggested exemption simplifies the administrative task by eliminating the difficulty of separating out religious beliefs from the continuum of sincerely held beliefs which may be the basis for conscientious objection. Instead it concentrates on making the single factual determination of sincerity which draft boards have had much experience in making under the current exemption. Their expertise will hopefully improve through focus on this one factual issue. Admittedly, eliminating the religious limitation

128 See notes $46-49$ supra and accompanying text.

129 National Service Act of 1948, 11 \& 12 Geo. 6, c. 64 \& 17. Conscription is, however, no longer in effect in Great Britain. National Service Act of 1948, 11 \& 12 Geo. 6, c. 64 § 61, as amended, Stat. Instr., 1953, No. 1771 (liability ended for all born after Dec. 31, 1940). The draft was ended in December 1960, Call up of Men to the Forces 1957/1960, CMnd. No. 175, at 2 (1957), and National Service in December 1962, Statement of Minister of Defense, 600 H.C. DEB. (5th ser.) 1142 (1959).

130 See Hayes, The Ghallenge of Conscience 382-83 (1949).

131 The popularity of a war as reflected by the extent of the national consensus as to the correctness of the course pursued may have some effect on the rate of objection. In an unpopular war the "marginal" objector should tend to claim an exemption more readily than in a popular war in which the supposed moral force behind his country's position may tend to negate some of the moral basis for objection. This tendency for increased claims in unpopular wars should not result in a great many extra claims; if the war is so unpopular that many such claims do arise, it might be better to question the adequacy of the democratic process at that time rather than the desirability of the exemption.

13262 Stat. 604, 50 U.S.C. App. § 456(j) (1964). 
will cause stress to be put on this difficult determination of sincerity. Thus the falsification of claims may increase due to the lack of the check on the determination of sincerity which the religious limitation provided. Yet even with the religious limitation some people surely falsify claims now. Some of the current false claims and some of the new attempts should be caught through the additional expertise gained from narrowing the inquiry. More importantly, the claimant under the broader exemption will continue to be required to present evidence showing a long, or extremely convincing, record in support of his claim. The extensive investigation which each claimant receives is an effective further deterrent to spurious claims. ${ }^{133}$ An additional deterrent is found in the stigma still attached in American society to the assertion of conscientious objection. ${ }^{134}$ Thus any increase in the falsification of claims should not be sufficient to require rejection of the suggested exemption.

The benefits, in terms of clear constitutionality, consonance with political theory, and fairness, derived from the expansion of the scope of the conscientious objector exemption to include all objectors without regard to religious belief thus seem to outweigh any costs incurred, in terms of loss of manpower, and therefore this change in the draft law is a desirable policy for Congress to pursue.

133 There is an extensive FBI investigation and a Department of Justice hearing report for every appeal from the denial of the exemption by a local board. 32 C.F.R. $\S 1626.25$ (1962).

134 Sibley \& Jacob, Conscription of Conscience, 315-19, 459-64 (1952); Crespi, Public Opinion Toward Conscientious Objectors (pts. 2-3), 19 J. PsxchologY 209, 251 (1945). Admission to the bar may be denied to an objector on that ground alone. In re Summers, 325 U.S. 561 (1945). 